\title{
OPTIMALISASI KUALITAS BALITA MELALUI PELATIHAN TENTANG SDIDTK PADA KADER DAN PEMBINA PANTI ASUHAN KASIH
}

\section{The Optimization Of Toddlers' Growht And Development Using Edsgd Training On Kader And Care Giver Of Children In Kasih Orphanage}

\author{
${ }^{1}$ Eufrasia Prinata Padeng, ${ }^{2}$ Putriatri Krimasusini Senudin, ${ }^{3}$ Dionesia Octaviani Laput \\ Unika Santu Paulus Ruteng, PRODI DIII Kebidanan \\ rinny.padeng90@gmail.com
}

\begin{abstract}
ABSTRAK
Masa depan suatu bangsa tergantung pada keberhasilan anak dalam mencapai pertumbuhan dan perkembangan yang optimal. Stimulasi yang tepat akan merangsang otak balita sehingga perkembangan kemampuan gerak, bicara dan bahasa, sosialisasi dan kemandirian pada balita berlangsung optimal sesuai dengan umur anak. Deteksi dini penyimpangan tumbuh kembang perlu dilakukan untuk dapat mendeteksi secara dini adanya penyimpangan tumbuh kembang balita termasuk menindaklanjuti setiap keluhan orang tua terhadap masalah tumbuh kembang anaknya. Stimulasi deteksi yang dilakukan di Posyandu masih belum lengkap, hanya penimbangan dan pengukuran tinggi badan, sehingga kader belum mampu melakukan deteksi dini secara komprehensif. Kegiatan ini bertujuan untuk memberdayakan kader serta penambahan ilmu tentang tumbuh kembang anak kepada orang tua asuh di Panti Asuhan. Sasaran pelatihan ini adalah Kader dan pembina panti asuhan. Hasil yang diharapkan adalah para kader dan pembina panti asuhan dapat melakukan Stimulasi Deteksi Dini dan Intervensi Tumbuh Kembang (SDIDTK) pada anak balita lebih khusus pada anak-anak di Panti Asuhan Kasih.
\end{abstract}

Kata Kunci : Kader, Peyimpangan, Stimulasi Deteksi Dini dan Intervensi Tumbuh Kembang

\begin{abstract}
The bright future of a country depends on its effort to optimalize children growth and development by provided proper ways to stimulate children growht and development. The right stimulation will stimulate the brain and increase motorik, speech and language, social and autonomy of children based of age. There for the early detection to find out abnormality in children's growth and development is important especially to follow up abnormality that found by parents during child' growth and development. Unfortenetly early detection and stimulation conducted by posyandu as primmary health care for children only focuse on weight and height measurement and neglect another important aspect. Kader as social worker in Posyandu didnt provide comperenship early detection due to the lack of knowledge. The aim of this training is to educate and empower kader and care giver of Orphanage. The target of this training is Kader of Posyandu and the cafe ggiver of orphanage. The expected result is that Kader and care giver of orphanages can conduct Early Detection and Stimulation of Growth and Development (EDSGD) in todler to optimalize their growth and development.
\end{abstract}

Keywords : Kader, Abnormality, Early Detection and Stimulation of Growth and Development

\section{PENDAHULUAN}

Stimulasi, Deteksi Dini dan Intervensi Dini gangguan tumbuh kembang anak harus diselenggarakan secara komprehensif, berkualitas dan berkelanjutan oleh tenaga kesehatan dan petugas lintas sektor. Pemantauan secara komprehensif dimaksud melalui kegiatan Stimulasi yang memadai, deteksi dini dan intervensi dini. Pemantauan pertumbuhan dilakukan pada anak usia 0-72 bulan melalui penimbangan berat badan setiap bulan dan pengukuran tinggi badan setiap 3 bulan serta pengukuran lingkar kepala sesuai jadwal. Pemantaun penimbangan ini dilakukan setiap 3 bulan pada anak usia $0-12$ bulan dan setiap 6 bulan pada anak usia 12-72 bulan (Mushaf, 2017) 
Masa depan suatu bangsa tergantung pada keberhasilan anak dalam mencapai pertumbuhan dan perkembangan yang optimal. Tahun-tahun pertama kehidupan, terutama periode sejak janin dalam kandungan sampai anak berusia 2 tahun merupakan periode yang sangat penting dalam pertumbuhan dan perkembangan anak. Periode ini merupakan kesempatan emas sekaligus masa-masa yang rentan terhadap pengaruh negatif. Deteksi dini penyimpangan tumbuh kembang perlu dilakukan untuk dapat mendeteksi secara dini adanya penyimpangan tumbuh kembang balita termasuk menindaklanjuti setiap keluhan orang tua terhadap masalah tumbuh kembang anaknya. Apabila ditemukan adanya penyimpangan, maka diakukan intervensi dini penyimpangan tumbuh kembang balita agar tumbuh kembangnya kembali normal atau penyimpangannya tidak semakin berat (Kementerian Kesehatan RI, 2016)

Optimalisasi kualitas anak balita menjadi tanggung jawab bersama, baik keluarga, guru, orang tua, masyarakat maupun pemerintah. Berbagai upaya juga telah dilakukan mulai dengan Posyandu dan PAUD. Posyandu diharapkan mampu memberikan pelayanan dalam pemantauan pertumbuhan, perkmebangan, gizi anak balita. PAUD diharapkan mampu memberikan pelayanan kebutuhan dan minat anak apakah ada penyimpangan atau tidak. Hasil penelitian menyebutkan bahwa masih tingginya tingkat kader yang tidak aktif serta masih banyak kader serta guru yang tidak mendapatkan pelatihan SDIDTK (Stimulasi Deteksi Dini dan Intervensi Tumbuh Kembang), Ini berdampak pada cakupan pemantauan kegiatan program ini. Dengan demikian, perlu pelatihan SDIDTK (Stimulasi Deteksi Dini dan Intervensi Tumbuh Kembang) pada kader dan guru (Rizki et al., 2016)

Panti Asuhan Kasih Dongang merupakan panti asuhan yang berada di kabupaten Manggarai. Panti asuhan ini dibawah naungan yayasan "Hati Nurani". Berdasarkan studi awal yang dilakukan, di Panti Asuhan Kasih Dongang, anak balita belum pernah di pantau penyimpangan tumbuh kembangnya. Pembina panti asuhan juga belum mengetahui cara melakukan deteksi dini penyimpangan pada anak balita.

Permasalahan yang dialami oleh mitra diantaranya adalah pelayanan posyandu hanya terbatas pada penimbangan berat badan saja belum sampai pada deteksi dini pentympangan pertumbuhan. Kader juga belum memahami cara melakukan deteksi perkembangan balita. Hal ini menyebabkan tidak dapat dilakukan deteksi dini gangguan perkembangan balita, sehingga terhambatnya intervensi dini gangguan perkembangan yang ada.

Tim pelaksana kegiatan, merespon permasalahan tersebut dengan menyelenggarakan Pengabdian Masyarakat berupa pelatihan SDIDTK (Stimulasi Deteksi Dini dan Intervensi Tumbuh Kembang) kepada pembina panti asuhan dan juga kader.

\section{METODE}

Kegiatan ini dilakukan dengan metode wawancara, pemeriksaan fisik dan juga pelatihan SDIDTK kepada kader dan pembina Panti Asuhan. Sedangkan untuk pemeriksaan fisik yang dilakukan adalah pengukuran tinggi badan serta berat badan anak .

Alat dan bahan yang digunakan dalam kegiatan ini adalah kuesioner SDIDTK, Kertas, Bola, Balpoint, medline, timbangan berat badan.

Kegiatan ini dilakukan di Panti Asuhan Kasih Dongang melalui beberapa tahapan kegiatan yaitu : penetapan sasaran dengan pembina panti asuhan dan kader, penyusunan materi terkait SDIDTK, rencana pelaksanaan kegiatan, membuat ijin pelaksanaan, setelah mendapatkan ijin pelaksanaan tahapan terakhir dalam kegiatan ini adalah melakukan pelatihan SDIDTK kepada pembina panti asuhan dan kader dengan melihat perkembangan dan tumbuh kembang anak balita di panti asuhan.

\section{HASIL DAN PEMBAHASAN HASIL}

Kegiatan dilakukan selama dua hari dengan kriteria peserta sebagai berikut :

1. 15 orang anak panti asuhan berusia 0-6 bulan

2. 2 orang kader dari wilayah kerja puskesmas Lao

3. 1 orang pembina panti asuhan 
Hasil yang diperoleh saat pelatihan adalah dari 15 orang anak di Panti Asuhan Kasih sebagian besar mengalami penyimpangan sehingga dapat mempengaruhi kualitas tumbuh kembang anak. Adapun faktor pemicu terjadinya penyimpangan ini adalah dilihat dari faktor luar (eksternal), faktor pasca persalinan dan juga aspek perkembangan yang meliputi motorik kasar dan halus. Penyimpangan yang didapatkan selama kegiatan di panti asuhan lebih cenderung kepada masalah gizi anak, Psikologis, lingkungan pengasuhan dan aspek perkembangan motorik kasar dan halus yang menyebabkan terhambatya tumbuh kembang anak.

Dengan adanya kegiatan ini para kader dan pembina panti asuhan merasa sangat bermanfaat karena melalui pelatihan ini mereka dapat mengetahui tumbuh kembang dan penyimpangan dan masalah yang terjadi, sehingga sedini mungkin masalah dapat diatasi.

\section{PEMBAHASAN}

Kegiatan berlangsung selama dua hari di panti asuhan kasih Dongang . kegiatan ini diawali dengan wawancara kepada pembina panti asuhan dan juga kader di wilayah setempat. Setelah dilakukan wawancara, dilakukan pelatihan SDIDTK kepada kader dan pembina Panti Asuhan, pelatiahan SDIDTK langsung kepada sasarannya yaitu anak berusia 0-6 bulan sebanyak 15 orang.

Dari hasil pengukuran SDIDTK ini ditemukan penyimpangan pada ke-15 anak tersebut. penyimpangan ini disebabkan karena beberapa faktor

1. gizi anak

2. Psikologis,

3. lingkungan pengasuhan
4. aspek perkembangan motorik kasar dan halus yang menyebabkan terhambatya tumbuh kembang anak.

\section{KESIMPULAN}

Pelatihan yang telah dilaksanakan mampu meningkatkan pengetahuan dan kemampuan kader dan juga pembina panti asuhan dalam mendeteksi tumbuh kembang anak balita. Diharapkan materi pelatihan yang sudah didapatkan benar-benar diterapkan dalam kehidupan sehari-hari .

Saran dalam pelaksanaan pengabdian ini adalah diharapkan kepada petugas kesehatan melakukan kegiatan berupa penyuluhan dan pelatihan pendeteksian tumbuh kembang balita dan juga penyuluhan sehingga lebih dini diketahui jika ada penyimpangan

\section{DAFTAR PUSTAKA}

Kementerian Kesehatan RI. (2016). Pedoman Pelaksanaan Stimulasi, Deteksi dan Intervensi Dini Tumbuh Kembang Anak.

Mushaf. (2017). Peraturan Menteri Kesehatan. Journal of Chemical Information and Modeling, $\quad 8(9), \quad 1-58$. https://doi.org/10.1017/CBO9781107415 324.004

Rizki, M., Budi, I. S., \& Destriatania, S. (2016). Analisis Kinerja Petugas Pelaksana Stimulasi Deteksi Intervensi Dini Tumbuh kembang Balita dan Anak. 7(November), 182-190. https://doi.org/https://doi.org/10.26553/ji km.2016.7.3.182-190 